\title{
"It's Morning Again in America": How the Tuesday Team Revolutionized the Use of Music in Political Ads ${ }^{1}$
}

\author{
PAUL CHRISTIANSEN
}

\section{Television Commercials and Their Music in 1984}

The year 1984 introduced many memorable ads and ad campaigns that remain well known. These include ads for Apple Macintosh ("1984”), McDonald's ("It's a Good Time for the Great Taste of McDonald's)," Burger King ("The Midnight Zone," which riffed on The Twilight Zone series), Wendy's ("Where's the Beef?" and Kool and the Gang singing "Celebrate" with new lyrics to peddle Wendy's new product Crispy Chicken Nuggets), Coors Light (“The Silver Bullet”), Folgers (“The Best Part of Wakin' Up is Folger's in Your Cup!”), Coke (“Coke is it”), and Pepsi (Michael Jackson's Pepsi Generation ads).

Advertising was ever-present at this time. Ad agencies and the clients they served in early 1984 sought to connect their products to the approaching Los Angeles Summer Olympics through crossmarketing campaigns, though not always with great success. (Most disastrous was the McDonald's idea to give away free food and drink for every medal U.S. athletes earned; the Soviet Union's decision to boycott these games led to the U.S winning by far the most medals, almost three times more than second-place West Germany.) ${ }^{2}$ Perhaps the most powerful connection to the Olympics that year was "1984," the Apple Macintosh ad directed by Ridley Scott. This ad seems to have transformed the landscape of television advertising by introducing an authentically cinematic aesthetic. (It should be noted that the actual product is never shown in "1984," and this comports with the increasing association of companies with lifestyle and the concomitant abstraction of advertising from the actual benefits of the products being pitched.) I discuss this ad briefly below.

MTV's inception in 1981 likewise had an indelible impact on the aesthetic of the television commercial. One reason for this is that directors of music videos often became directors of TV commercials. But making the connection even more explicit were the 1984 "Pepsi Generation" ads that Michael Jackson made really as music videos in miniature. It was in the 1980s when ads started most deliberately to create a sort of alternate reality where magic and fantasy intertwine with and are inseparable from reality. So both the image of Michael Jackson leading children dancing to his "Pepsi Generation" music and Ridley Scott's grim vision of PC dystopia contribute to the increasingly variegated universe of advertising discourse.

\footnotetext{
${ }^{1}$ An earlier version of this article was presented as a paper at the Annual Meeting of the American Musicological Society in 2012 in New Orleans. I thank Matthew Killmeier and Peter Martin for their insightful comments on this earlier version. ${ }^{2}$ Another example of corporations trying to associate their products with already popular cultural phenomena was the illconceived 1984 "Mister Rodney" campaign meant to connect Burger King food to the massively popular icon of children's television broadcasting, Mr. Rogers. After Fred Rogers raised objections to the ad to a senior vice president of Burger King, stating that children might be "very confused" seeing someone looking like him shilling for a corporation, the company quietly pulled the ad.
} 
Music in television commercials in 1984 tends to be warm, orchestral music or else rock or New Wave music. Some ad music still consisted of jingles. Most performers eschewed composing music for commercials; in the 1980s, many artists saw associating their music with commercial products as "selling out." Those who did so were at times judged harshly (as Michael Jackson was from his first association with Pepsi). One need only recall the Beatles bringing suit against Nike for the 1987 "Revolution" ad that used a song from their White Album. Timothy D. Taylor convincingly argues that because music production in the twenty-first century is now almost invariably associated with corporate sponsorship, the phrase "selling out" these days is largely meaningless. ${ }^{3}$

\section{"Prouder, Stronger, Better"}

The year 1984 was also a watershed in the use of music in U.S. television political advertising. Following on the heels of technological developments in sound reproduction in television sets and MTV's introduction three years earlier, the 1984 presidential campaign saw striking changes in the way ads were conceived and constructed. "Prouder, Stronger, Better"- known popularly as "Morning in America" and produced for Ronald Reagan's re-election campaign—used music as never before in a political ad. Whereas previously music was merely accompaniment to an ad's voiceover and images, here, for the first time, music was the argument itself. Sweeping orchestral gestures, frequent chromatic modulations, and suspended chords led to a convincing resolution ending with Reagan's name and picture. "Morning in America" stood out from other political ads and set a new standard for integration of image, music, and text.

The visual tableaux of "Morning in America" support the music's poetic appeal. The ad begins with scenes of everyday life as Americans begin their morning. ${ }^{4}$ We see a lobster boat; a man exiting a taxi; a farmer backing up a tractor; a paperboy on a bicycle throwing a paper in the background as a man waves, smiles, and catches a ride to work; a family moving out of a house; and a couple getting married with grandparents looking on. Lending a dreamy cast to the ad, soft light appears in every scene, at first only as points of light — headlights of car, bike, and tractor, candle flames, wedding grandmother's pearl earringsbut it gradually increases throughout the ad. (Oddly, the wedding scene also seems to be bathed in soft morning light, even though weddings typically occur later in the day.)

Nowadays, television political advertisements are one-minute, thirty-second, or even fifteen-second affairs. In this extremely compressed timeframe, the ad's producers work to create in viewers' minds maximal meaning in minimum time. Thus music, like the visual and textual elements, conforms to its own specific advertising norms. Compared to earlier ads, "Morning in America" stands like a cathedral in the desert of political advertising, inspiring awe and seemingly out of place. "Morning in America" was only the beginning. Since then, campaigns have been producing ads with incredible musical subtlety and compelling soundscapes. ${ }^{5}$

\footnotetext{
${ }^{3}$ See Timothy D. Taylor, The Sounds of Capitalism: Advertising, Music, and the Conquest of Culture (Chicago: University of Chicago Press, 2012), especially Chapter 8. http://dx.doi.org/10.7208/chicago/9780226791142.001.0001.

${ }^{4}$ All of the people visible in this commercial are white, save two girls near the end of the ad who look up at a raised flag-one Latina and one African American.

${ }^{5}$ Examples are legion, but some of the most aurally persuasive commercials include George H. W. Bush's "Tank Ride" (1988), Bill Clinton's "Drums" (1996), George W. Bush's “Dangerous World” (2000) and "Wolves” (2004), and Barack Obama's "Firms" (2012).
} 

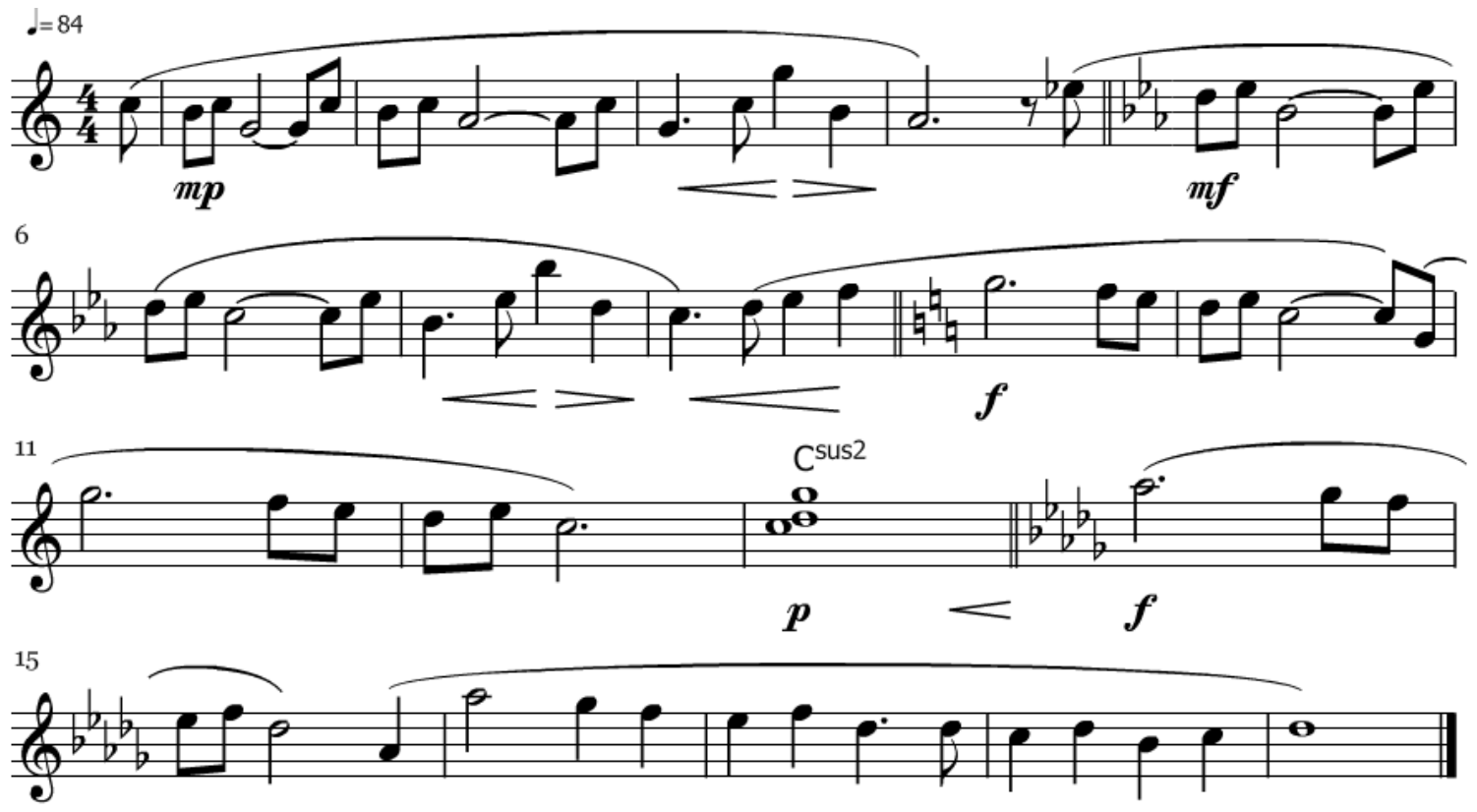

Symphonic music - clarinet, piano, strings, horns prominent Total time: 1 minute

\begin{tabular}{lclll} 
Time & Theme & Key & Chords & Length \\
\hline $00: 00$ & A & C major & I-IV-I-IV & $4 \mathrm{~mm}$. \\
$00: 13$ & A & E-flat major & I-IV-I-IV & $4 \mathrm{~mm}$. \\
$00: 25$ & B & C major & I-IV-I-IV & $4 \mathrm{~mm}$. \\
$00: 36$ & X & C sus2 & & $1 \mathrm{~m}$. \\
$00: 40$ & A' & D-flat major & I-IV-I-IV-V-I & $6 \mathrm{~mm}$.
\end{tabular}

\section{NARRATOR'S VOICEOVER:}

It's morning again in America

Today, more men and women will go to work than ever before in our country's history

With interest rates at about half the record highs [MODUL - E-flat] of 1980

Nearly 2,000 families today will buy new homes

More than at any time in the past four years

This afternoon 6,500 young men [MODUL - C] and women will be married

And with inflation at less than half what it was just four years ago

They can look forward with confidence to the future [HIGH CHIME, SUS CHORD]

It's morning again in America [MODUL - D-flat]

And under the leadership of President Reagan

Our country is prouder, and stronger, and better

Why would we ever want to return to where we were less than four short years ago?

TEXT: PRESIDENT REAGAN / PAID FOR BY REAGAN-BUSH '84

[Reagan's face on button, miniature gold-decorated American flag with two gold tassels]

Example 1: Score and transcription of "Prouder, Stronger, Better"

\footnotetext{
${ }^{6}$ The transcription is mine.
} 
Music is the sine qua non of this ad. Dominating the discourse and supported by an insistent narrator and images meant to generate positive feelings in viewers, the music evokes contentment, satisfaction, and pride. Production values in "Morning in America" are high, and much consideration was given to how the ad can work as a unified whole, even as an aesthetic unity. ${ }^{7}$ Many call the ad "slick." Most viewers are unaware of how skillfully this message was crafted and polished to generate positive emotional associations with Reagan. Indeed, without analysis, we would scarcely be able to articulate exactly how this ad functions so effectively. Here music convinces not by logical appeal; it persuades through subterfuge.

It should therefore not surprise that the Reagan/Bush team engaged the services of a group of Madison Avenue advertising executives, who called themselves the Tuesday Team, to create this and other ads such as "Russian Bear." ${ }^{8}$ The Tuesday Team comprised volunteers, who worked fervently and for free. Heading the team was Sig Rogich, who was joined by Phil Dusenberry, Jerry Della Femina, and Tom Messner; their media consultant was Roger Ailes. This collaboration was to become the beginning of a long and fruitful association between Ailes and the Republican Party, one which continues to the present day: currently, Ailes is Fox News Channel president and Fox Television Stations Group chairman, and the relationship between Fox News and the Republican Party probably needs no explanation. ${ }^{9}$ Ailes was responsible for creating the 1988 ad that made Willie Horton a household name-just as he had promised to do-and helped George H. W. Bush defeat Michael Dukakis.

The Tuesday Team's final product revolutionized political advertising as we know it. Narrated by advertising executive Hal Riney and featuring a series of scenes meant to depict a newfound optimism in America during Reagan's first term, the ad presented itself as a positive spot about Reagan's accomplishments but really contained numerous rhetorical attacks on the Carter/Mondale administration, ending, "Why would we ever want to return to where we were less than four short years ago?" The enthymeme that the audience is expected to complete is "You mean return to when we weren't as proud, strong, or good? Well, of course we wouldn't!"

Many observers trace much of Reagan's resounding success that year to this compelling ad, ${ }^{10}$ which first ran on September 17, 1984. The Reagan/Bush campaign was far more innovative in advertising than that of their opponents, Mondale and Ferraro. The professionally produced, cinematically conceived Republican ads contrasted starkly with the rough-hewn, folksy Democratic ads. Could the American public have connected professionalism in advertising to professionalism in the White House? Phil Dusenberry thought so and said as much in an interview for PBS's Online NewsHour: "We used topnotch filmmakers, topnotch editors, music people, and people did say it was slick. But as I said before, slick translates into really being professional and not looking like, you know, the primitive bio-films of the past." ${ }^{11}$ In the event, the Republican triumph that year was so complete that Mondale won the electoral

\footnotetext{
${ }^{7}$ In 1936, Walter Benjamin wrote of fascists aestheticizing politics, and "Morning in America" is by any standards an artistic endeavor.

8 "Russian Bear" implied that the USSR presented an existential threat to the US that could only be dealt with in the context of Reagan's "Peace through Strength" doctrine. The ad's ursine metaphor proved very effective-so much so, that the 2004 Bush campaign decided to use a vulpine metaphor for terrorists in their "Wolves" ad. For more on how music works in this ad, see Killmeier and Christiansen, "Wolves at the Door: Musical Persuasion in a 2004 Bush-Cheney Campaign Ad," MedieKultur: Fournal of Media and Communication Research 50 (2011): 157-77.

${ }^{9}$ The infamous Willie Horton "Revolving Door" ad in the 1988 presidential campaign was produced for the Bush/Quayle campaign by Larry McCarthy, who had worked for Roger Ailes. George H. W. Bush denied involvement in the ad's creation.

${ }^{10}$ Not all scholars agree on this point. Darrell M. West, in his book Air Wars: Television Advertising in Election Campaigns, 1952-2008, $5^{\text {th }}$ ed. (Washington, DC: CQ Press, 2010) lists what he calls "memorable ads" from 1984 to 2008. The only ad from the Reagan/Bush 1984 campaign he lists is "Bear in the Woods."

${ }^{11}$ Phil Dusenberry, in an interview with Jim Lehrer for PBS's Online Newshour
} 
votes only in his home state of Minnesota and in the District of Columbia.

In order to see how innovative "Morning in America" was, let's examine the state of the art for political advertising just four years earlier, in a Jimmy Carter ad entitled "State," which uses music more than any other political ad in 1980. "State" shows Carter as president representing America abroad. There is no attempt at subtle musical persuasion here; music only serves to characterize the settings as an economic summit, a review parade, and a state funeral. "State" begins and ends with martial fanfares intended to remind voters of Carter's Annapolis education and considerable military experience in contrast to his opponent, Reagan, who as former governor of California, had no foreign policy credentials. In the middle, we hear diegetic band music at state visits to Japan and China. Music in "State" embodies dignity, competence, and seriousness of purpose. From their inception in 1952 until 1980 with this ad, political spots were still trying to sell candidates based on personal attributes and job performance.

By 1984, however, ads were no longer overtly about competence, experience, or policy stances. They were starting to elevate style over substance, with music as one of the key agents of creating the style. Whereas music in Carter's "State" ad was diegetic and thus difficult to hear clearly or hear as a unified whole, "Morning in America" generated a powerful message with carefully calibrated underscoring. Production values in "Morning in America" reflected the wider trend in advertising to blur the line between content and advertising sponsoring that content.

Most striking musically about "Morning in America" are its three key changes, which raise the emotional stakes of the ad. Key changes are often used in popular songs to ratchet up listener engagement near the end of the song. Of pop modulations, Philip Ball writes:

In classical terms they are hardly modulations at all, but merely transpositions of key-what comes before bears none of the theoretical relationship to what comes after that true modulation entails, but is merely a repetition in a new key. We are not taken on a journey in harmonic space, but simply have the coordinate grid redrawn under our feet. ${ }^{12}$

Often, these harmonic resets are accompanied by other musical elements that create dramatic interest, such as swelling crescendos, cymbal crashes, and the like.

Key changes in "Morning in America" are direct modulations of the remote variety. The score moves initially to a key three flats removed and then back again, and finally to a key five flats removed. ${ }^{13}$ Indeed, this final chromatic semitone modulation could be said to musically embody the economic and social progress touted in the ad and it provides non-verbal support for the last line of text: "Why would we ever want to return to where we were less than four short years ago?" The exhilarating harmonic shift at the end of the ad lends Reagan what David Huron calls a "pump up" or "a gear change that injects fresh energy from the jolt." 14 This key change coincides with the resolution of measure 9's G to measure 14's Aflat.

If we accept that "it's morning again in America," then the new D-flat tonality could represent the dawning of a bright new day. We cannot return to the previous dark night, even if we wanted to. If I am wrong about the $\mathrm{C}$ to D-flat key change as a metaphor for progress, it could be that the flat key symbolizes a return to a bucolic past or an ancient mythology of America as wide-open spaces of unoccupied land. In other words, the America imagined in the Largo of Antonín Dvořák's "New World" Symphony

https://web.archive.org/web/20140119041918/http://www.pbs.org/newshour/bb/media/july-dec00/image 8-3.html.

${ }^{12}$ Philip Ball, The Music Instinct (Oxford: Oxford University Press, 2010), 191.

${ }^{13}$ There is something uncanny about popular music-type modulations in orchestral music.

${ }^{14}$ David Huron, Sweet Anticipation: Music and the Psychology of Expectation (Cambridge, MA: MIT Press, 2006$), 191$. 
(incidentally, also in D-flat). Whatever the specific interpretation, though, the shift from C to D-flat has a positive musical meaning that viewers are expected to associate with the incumbent president. The D-flat key change does not provide support for any quantifiable measure of Reagan's superiority. What it does do, however, is provide an emotional springboard for the words "and under the leadership of President Reagan, our country is prouder, and stronger, and better."

At any rate, the final key change is preceded by a dramatic musical colon: a subito piano sus 2 chord on C juxtaposed against a picture of the U.S. Capitol building bathed in soft dawn light. This musical gesture creates suspense and anticipation resolved by the move to D-flat accompanied by a crescendo, sweeping glissando, and cymbal roll as we see a flag being raised in a rustic setting with the voiceover "It's morning again in America." This final section, lasting twenty seconds or a third of the entire length of the ad, sounds as though it is slowing down in anticipation for the final cadence. In fact, here the main theme is augmented. This key change from C to D-flat is marked by a striking visual aspect: dawn light is transformed into full daylight for the remainder of the ad.

Although it has a pleasing contour, the theme itself is static, its chief interest coming from instrumental timbre and the modulations it goes through. It is static because the fundamental motion in the first two A sections is mere oscillation between scale degrees 5 and 6 in the first two key areas. The same holds true for the B and A' sections, with oscillation there being between 5 and 1 in the final two key areas. Similarly noteworthy is the legato phrasing throughout, which lends the ad a soothing and reassuring cast. High shimmering violins on $\mathrm{G}$ at the beginning seem to evoke the sun's rays peeking over the horizon.

Ad creators use a type of shorthand to convey their intended meaning, partly in the interest of time, and partly to fix the message in viewers' minds. This is true for music as well as for visual images and words. It is not just that the combination of visual images, voiceover, and music in "Morning in America" are together more than the sum of its parts; each part by itself is essentially unconvincing. The images are merely a disjunct series of pictures that we are meant to associate with America and more specifically with pleasant feelings about the U.S. (a paperboy, wedding scenes, the Capitol, people raising American flags, a sunlit American flag fluttering in the breeze, a miniature flag next to a campaign button with Reagan's picture, and so on). As Nicholas Cook remarks, writing about music in television commercials: "Music that is custom-written for a commercial frequently makes little or no sense when heard by itself, away from the context of words and pictures. Typically it is far too fragmentary to make sense in its own terms. Its logic is not the logic of concert music." 15

Campaign ad music is more than a soundtrack for a minidrama. A typical viewer does not recognize how much thought and effort goes into crafting emotional appeals in political ads. Hardly would she be able to articulate exactly how this ad functions so effectively. Music sets the tone for the whole ad and provides a sympathetic backdrop to the voiceover-together they form a unified whole. Music draws the whole together and channels the discourse; it is the binding element in nonverbal or poetic arguments. While music in "Morning in America" does not obey all rules of common practice tonal harmony, it does have its own internal logic and narrative arc.

Music belongs to the aesthetic dimension that images also inhabit. The key changes operate in parallel to the text, but in fact, music supersedes the text of the voiceover in importance. The ad's appeal to logos is minimal. For instance, the second line of the ad, "Today, more men and women will go to work

${ }^{15}$ Nicholas Cook, Analysing Musical Multimedia (Oxford: Oxford University Press, 1998), 9. 
than ever before in our country's history," implies that Reagan is responsible for a decrease in unemployment since the Carter administration. The line does not assert this so baldly, though; it merely allows the viewer to connect the assertion to the candidate, leaving the thoughtful viewer to wonder whether the increase is accounted for merely by an increase in population, a decline in unemployment claims, or whether other factors irrespective of who is president may be responsible for the increase in employment. Assertions in many political ads do not stand up to scrutiny, and those in "Morning in America" are no exception. But since the main appeal is emotional, cogent arguments are not de rigeur; indeed, they might distract from the powerful emotional appeal.

Further advancing the emotional dimension of the ad is the grain of Hal Riney's voice, which marks him as an avuncular, folksy figure, someone to be trusted. In conjunction with the music, this voice lends gravitas as well as reassurance. In Barthes's terms, Riney's voice is the narrator equivalent of that of his favorite singer Charles Panzera-thick with character and grit, satisfyingly material. ${ }^{16}$ We hear Riney's body in his voice. This corporality of the narrator's voice is analogous to what Barthes, following Julia Kristeva, called geno-song. Interestingly, the timbres of the instruments emphasized in "Morning in America"strings, and especially clarinet and horns-are likewise closely connected to the bodies that produce those sounds.

Were there any precursors to "Morning in America"? Nine months prior to the first airing of "Morning in America," Apple's "1984" appeared on national television, introducing a cinematic feel to TV ads. Set in an Orwellian futuristic dystopia, Ridley Scott's ad painted IBM PC owners as a horde of gray, male, laborer drones, contrasted starkly by the Mac user as a colorful, voluptuous, athletic woman. It was hard to miss the clear evocation of the Soviet Union in the first group and the U.S. in the lone female figure (the Los Angeles Olympics were mere months away). It first ran on December 31, 1983, and then again on January 22, 1984, during the second half of the most watched television event in the U.S., the Super Bowl.

Music connotes rather than denotes. It can evoke associations, but only in the most abstract manner. One can speak about internal relationships in music_about how various musical elements interact with each other-but such analyses are necessarily divorced from any concrete associations one might make with the music. Conclusions drawn from purely musical analyses can only address strictly musical concerns. It is only when the music is given images and text does the message come into focus. Yet when interrogated, music casts a sideward self-effacing glance, modestly gainsaying any persuasive role in political discourse.

By no means naïve with regard to techniques of mass persuasion and able to harness the power of media, the Republicans had been, like the Democrats, still one-dimensional in their vision for how music could be used in political ads. It wasn't until the 1984 campaign that music truly began to persuade surreptitiously. The Tuesday Team in essence created a new musical genre: political ad music, carefully scored music joined seamlessly with images and voiceover, a self-contained rhetorical universe. Music and voiceover for the spot were created specifically to fit together line-by-line, with no jarring splices as we often see in older ads. It is music that doesn't call attention to itself.

\footnotetext{
${ }^{16}$ Roland Barthes, “The Grain of the Voice," Image - Music - Text, trans. Stephen Heath (New York: Hill and Wang, 1978), 179-89.
} 
We can see the Tuesday Team's legacy in recent political spots. "Morning in America" has had inordinate influence on the aesthetic of political ads to follow. The phrases "Morning in America" and "It's morning [again] in America" have been tropes in American culture since the ad first aired. Much of the positive feeling the ad evokes comes directly from the music. It is victor's music-Reagan was presented as a winner with his re-election seemingly a foregone conclusion-and it was to become a model for political ads to follow. ${ }^{17}$

\begin{abstract}
The year 1984 was a watershed in the use of music in U.S. television campaign advertising. Following on the heels of technological developments in sound reproduction in television sets and MTV's inception three years earlier, the 1984 presidential campaign saw striking changes in the way ads were conceived and constructed. "Prouder, Stronger, Better" - known popularly as "Morning in America" — used music as never before in a political ad. Whereas previously music was merely accompaniment to an ad's voiceover and images, here, for the first time, music is the argument itself. Sweeping orchestral gestures, frequent chromatic modulations, and suspended chords lead to a convincing resolution ending with Reagan's name and picture.

Previous scholarship on political advertising has scanted the importance of music in creating a persuasive message-studies tend to focus on analyses of rhetorical appeals in the voiceover or on the visual narrative. Yet music is often the sine qua non of an ad. Without music, the "Morning in America" spot is a nonsensical series of unrelated images strung together as backdrop for the voiceover. Only when music is introduced does the ad take on a powerful significance. Dominating the discourse and supported by an insistent narrator and images meant to generate positive feelings and a newfound optimism in America during Reagan's first term, the music evokes contentment, satisfaction, and pride. "Morning in America" is slick—production values are high and much consideration was given to how the ad could work as a unified whole, even as an artistic unity.
\end{abstract}

\footnotetext{
${ }^{17} \mathrm{Jim}$ Cole, political ad producer and co-owner of media firm Chi/Donahoe + Cole/Duffey, remarked in an interview with the author that the media consultants who worked with him as he was producing a Human Rights Commission ad for marriage equality specifically requested that the ad's music be "like 'Morning in America"' (personal interview, July 11, 2013).
} 